Jap. J. Psychol.

1968, Vol.39, No.2, 57-65.

\title{
時間，空間和よび速度評価の発達的研究 I
}

\author{
広島大学 \\ 松田文 小 $^{1}$
}

時間, 空間和よび速度評価のららの 2 者あるいは 3 者 の関係を岕つかった研究は多いが，それらは実験目的の 面から 2 つ大別されよ5。すなわち 1 つは時空相待現 象を安つかったもので，ここでは多くの場合刺激は静止 して沶り，それが継起的に点滅する(Abe, 1935 ; 阿部, 1936, 1937 a, b, c ; Cohen, Hansel \& Sylvester, 1955; Helson \& King, 1931; Scholz, 1924). 他方, 主観的 な速度評価の尺度を作る研究，あるいは主観的な時間， 空間和よび速度の間にも客観的なそれらの間の物理法則 飞類似した関係があるかどうかを調べる実験があり,こ れらに拈いては多くは刺激は動体である(Bonnet, 1964, 1965 ; Brown, 1931 a, b ; Ekman \& Dahlbäck, 1956; Johanson, 1962 ; Mashhour, 1964).

さて, これらの諸実験はいずれの場合も, 既知数之未 知数の関係に扣いて, 2 つたわられる. 今動体 $\mathrm{M}_{1}$ の 運動条件を $\mathrm{T}_{1}$ (時間), $\mathrm{E}_{1}$ (空間), $\mathrm{V}_{1}$ (速度)と乙, 各々 の主観的評価を $\mathrm{t}_{1}, \mathrm{e}_{1}, \mathrm{v}_{1}$ としょ5. 同様に動体 $\mathrm{M}_{2}$ に 対するものを $\mathrm{T}_{2}, \mathrm{E}_{2}, \mathrm{~V}_{2}$ 特よび $\mathrm{t}_{2}, \mathrm{e}_{2}, \mathrm{v}_{2}$ としよう。 ただし， $V_{1}=E_{1} / T_{1}, V_{2}=E_{2} / T_{2}$ である. 時空相待現象の 事態でも V 和よび、をカッコに入れて同様に考えること ができる。第 1 のやり方は Table 1 のIのように, $\mathrm{T}_{1}=$ $\mathrm{XT}_{2}, \mathrm{E}_{1}=\mathrm{YE}_{2}, \mathrm{~V}_{1}=\mathrm{ZV}_{2}$ をあらかじめ定め, $\mathrm{t}_{1}$ と $\mathrm{t}_{2}, \mathrm{e}_{1}$ と $\mathrm{e}_{2}$, あるいは $\mathrm{v}_{1}$ と $\mathrm{v}_{2}$ の関係をしらべる, すなおち, $\mathrm{t}_{1}=\mathrm{xt}_{2}, \mathrm{e}_{1}=\mathrm{ye}_{2}, \mathrm{v}_{1}=\mathrm{zv}_{2}$ の $\mathrm{x}, \mathrm{y}, \mathrm{z}$ を求める方法であ る。もら1つのやり方は，たとえば時間評価に関してみ ると, $\mathrm{V}_{1}=\mathrm{ZV}_{2}$ と客観的な速度関係を固定しておいて, 主観的な時間評価の関係が $\mathrm{t}_{1}=\mathrm{xt}_{2}$ になるように $\mathrm{T}_{1}$ と $\mathrm{T}_{2}$ の関係を調整する方法である。すすなわら $\mathrm{T}_{1}=\mathrm{XT}_{2}$ の Xを求める方法である。したがってこの方法では，時 間，空間，速度についての Table 1 のII のような $6 つ$ の事態を考えないと完全とはいえない。このよ5にぬと めると, 時間, 空間, 速度のすべてについてみようとす

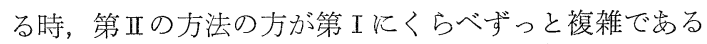
こと, そして第正の方法は時間, 空間, 速度の評価を求 める物理的事態がそれぞれことなるから，3 者の関係を

1 本研究は広島大学古浦一郎教授の指導のるとに扣こ なわれた。記して感謝の意を表す。
みようとする時，具合が悪いことがわかる．

未知数と既知数の関係とは別に, 実際に用いられる方 法もさまざまである。もっとも多いのほ一対継時比較矛 よび一対継時比較と実験者または被験者調整法を組合わ やたもの，一対継時比較による全系列法や恒常法等，そ してまれに再生法である. 一対比較法だけの場合, ぞら らが大または小という判断をするだけであれば簡単であ るが，それでは量的なことがわからない，そこで調整法 等を用いるのたが，こうすると判断の回数が非常に多く なる、そこで Mashhour (1964) は大または小という判 断でなく，何倍大または何倍小といら比の判断を求め て，1 回の一対比較で 1 つの量的結果を得た.

さて, このように実験目的, 実験方法はさまざまで心 るが, 今時間, 空間, 速度の各々の評価の依存関係とい ら観点のみから, 従来の研究結果をるとめてみよう。亦 ず，先述した未知数と既知数の関係がエであるような場 合の結果の表示は Table 2 のようにまとめられよう。i は kappa-effect とよばれているるので, 継時的にあら われる 2 点または 3 点によるAbe (1935), 阿部 (1936, 1937 a) の結果がこれにあたる. Cohen \& Cooper(1963) の, 被験者が自動車にのって移動するという事態での結 果もこれに属した. ii はtau-effectとよばれているもの にあたり，継時的にあらわれる3 点による阿部(1937b)， 触覚上刀点を用いた Helson \& King (1931) の結果がこ れにあてはまる。しかし，動体を用いた Mashhour (1964) の結果は ii'を示して特り, v-effectと彼はかり になづけた. Cohen, Cooper \& Ono (1963) の自分が 運動するという事態では, ii と $\mathrm{ii}^{\prime}$ を示す者が㴗滦半及 であった。速度については, Mashhour の結果が iii $^{\prime}$ を示した。彼はこれをl-effectと仮になづけた。

同様に未知数と既知数の関係が場合について考光 ると，6つの事態に各々相反する2つの結果がありう る、そこで簡単にするために，Iの場合の結果のあらわ し方にか光て、これまでの実験結果を示す. Cohen et al. (1955) の継起する 3 点を用いた実験の結果はｉである が，動体を用いた Bonnet (1965), Brown (1931 b) の 結果は i'である. Scholz (1924) の結果は ii でめり, 


\section{TABLE 1}

Two methods of experiments which examine interactions of time, space and velocity

in estimation, in the view-point of known qualities (fine type) which experimenters decides previously and unknown qualities (bold type) which subjects decide.

\begin{tabular}{|c|c|}
\hline $\begin{array}{l}\text { Number of } \\
\text { method }\end{array}$ & $\begin{array}{l}\text { Relations between known q } \\
\text { and unknown qualities }\end{array}$ \\
\hline$I$ & $\begin{array}{ll}\mathrm{T}_{1}^{\dagger}=\mathrm{XT}_{2}^{\dagger} & \mathrm{t}_{1}^{\dagger}=\mathbf{x}_{\mathbf{t}_{2}^{\dagger}}^{\dagger} \\
\mathrm{E}_{1}=\mathrm{YE}_{2} & \mathrm{e}_{1}=\mathrm{ye}_{2} \\
\mathrm{~V}_{1}=\mathrm{ZV}_{2} & \mathrm{v}_{1}=\mathbf{z v}_{2}\end{array}$ \\
\hline II & 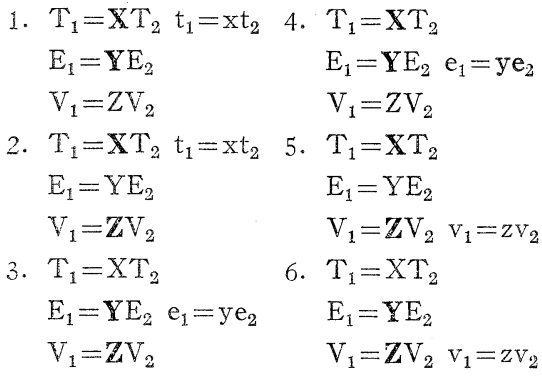 \\
\hline
\end{tabular}

$+\mathrm{T}_{i}, \mathrm{E}_{i}$, and $\mathrm{V}_{i}$ physical time, space and velocity belonging to the moving stimulus $M_{i}$ and $t_{i}, e_{i}$, and $v_{i}$ are subjective time, space and velocity.

TABLE 2

Results of experiments about interactions of time, space and velocity in estimation, in the case of method I.

When $X$ is constant, suppose that $x=f_{1}(Y)$ and $x=f_{2}(Z)$.

When $\mathrm{Y}$ is constant, suppose

that $y=f_{3}(Z)$ and $y=f_{4}(X)$.

When $Z$ is constant, suppose that $z=f_{5}(X)$ and $z=f_{6}(Y)$.

About $x \quad$ i. $f_{1}$ and $f_{2}$ are increasing monotonic functions ${ }^{\dagger}$ (kappa-effect), or

$i^{\prime}$. $f_{1}$ and $f_{2}$ are decreasing monotonic functions.

About $y \quad$ ii. $f_{3}$ is decreasing and $f_{4}$ is increasing monotonic function (tau-effect), or

ii'. $f_{3}$ is increasing and $f_{4}$ is decreasing monotonic function.

About $z$ iii. $f_{5}$ and $f_{6}$ are increasing monotonic functions, or

iii'. $f_{5}$ and $f_{6}$ are decreasing monotonic functions.

$\dagger$ Of course it is not enough to consider only monotonic functions. But it will do for the present.
Cohen et al. (1963)の自分が運動する後半の実䍄結果も iiである. Bonnet (1964), Brown(1931 a) の速度につ

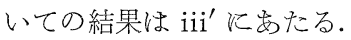

このように文てくると，これらの諸結果は目的にそっ て 2 つ大別される。すなわら，いくつふの静止刺激の 継起を用いた実験では，いわゆる tau-effect や kappaeffect がなりたら，動体を用いた実験では効果はむしろ 逆である。しかし，前者が 20 世紀初頭より多くの実験 結果堂持つ確立された事実であるのに対し，後者にはま だわずかの実験結果しかないところでこのような 2 群 の結果の不一致は興味深い, tau-effect の成立する時間 条件が㴗ぼ仮琴運動の時相と同じであること（Scholz， 1924), kappa-effect も運動印象をともなう時大きいこ と（阿部，1937b; Cohen et al., 1955）を考えると，実 験が静止条件で执こなわれているとはいえ，運動をふく んでいるのでめる。しかし，時間，空間，速度の 3 者の 依存関係を調べることを主目的とした実験はほとんどな く，また動体を用いた実験では，空間の枠組のはっきり してている事態を用いているものが多く，その場合 tau-

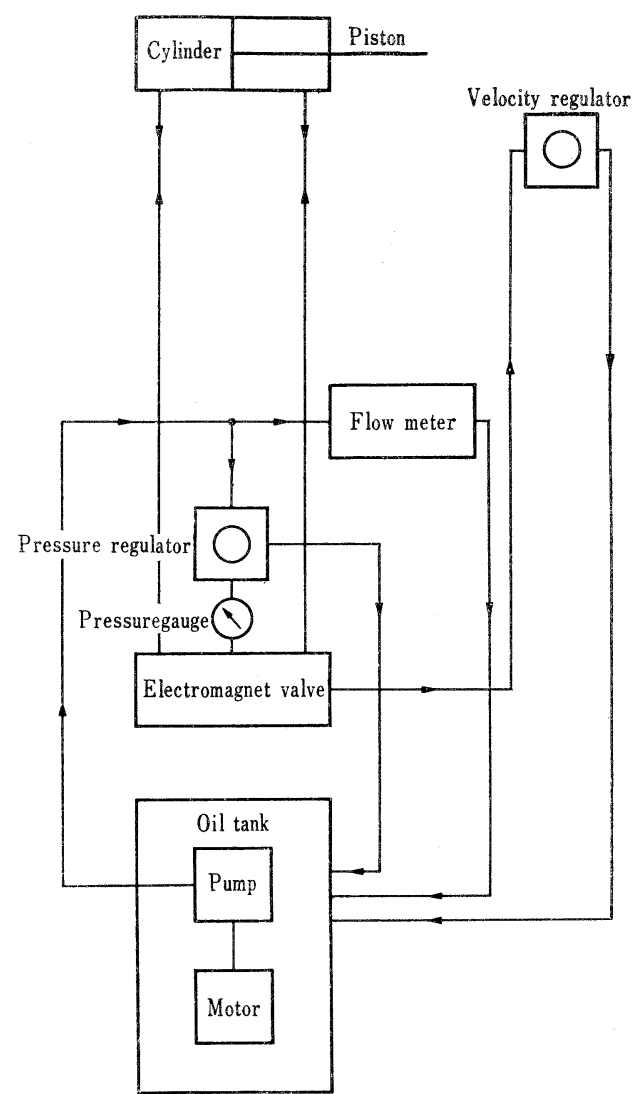

FIG. 1. A block diagram of the part of apparatus, velocity regulator by oil pressure. 
effect は当然期待できないで安ろう。

そこで，動体を用いた場合の時間，空間，速度の 3 者 ○閣係が時空相待現象を包括しえないるのか，ここでさ らに調べてみ不たい，そしてその際発達的研究妾行なう。 なぜなら，もし 3 者の間に依存関係があるならば，拉そ らく主客未分化な発達段階の低い年少児童の方がより依 存関係の強い評価邑し，成人は各々を独立により客観的 に判断することが可能であるら。したがって発達過程を 息じてみることが，一層この問題の解明へ近づく道だと

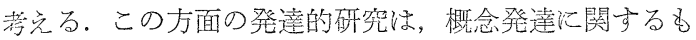
の密のぞけげ皆無である，時空相待現象に和いてさえ， 阿部（1936）が1少年にも成立したということを報告し ているにすぎない。

ところで，年少児を被験者とする場合，その実験方法 がくらさされね゙ならない、圭知数と既知数の関係は， 先に詳述したように，Iをとる力が実䔎事態に和いて も，結果の整理に彯てても而よりもはるかに簡単である ので，Iの方をとることにしょう。ささ具体的な方法で
めるが，1 対比較法だけでは量的な測定がでさない。全 系列法や調整法をくみあわせると，1つの量的值を得当 の多くの時間を要し，むきっぽい年少児童には適さな い,かといって Mashhourの上5な比判断，あるいは常 用単位を用いての言語的評価は小学校低学年では無理で ある、そこでここでは再生法を用いる。この方法の利点 は，著者の時間評洒の発達に関する研究 (1965 a， b, 1966）に执いてよく示されている。この方法の難点は， 沶そらく，時間，空間，速度を被験者が簡单飞再生しう る装置を作ることのむつかしさであるう。

\section{方法}

䒾䈯 ${ }^{2}$ 装置は運動を劧こすための油圧系の部分 ${ }^{3}$, 刺 激提示のための電気的部分，呿よび被験者の反忘のため の装置の 3 つねわ梳らる。

まず油圧系の部分についてのべる。油の流れの系路い Fig. 1 のと䉼りで岁る。電磁弁のスイッチ索切りか壳 ることにより，シリンダ一は左右どちらにも進虫し，ど

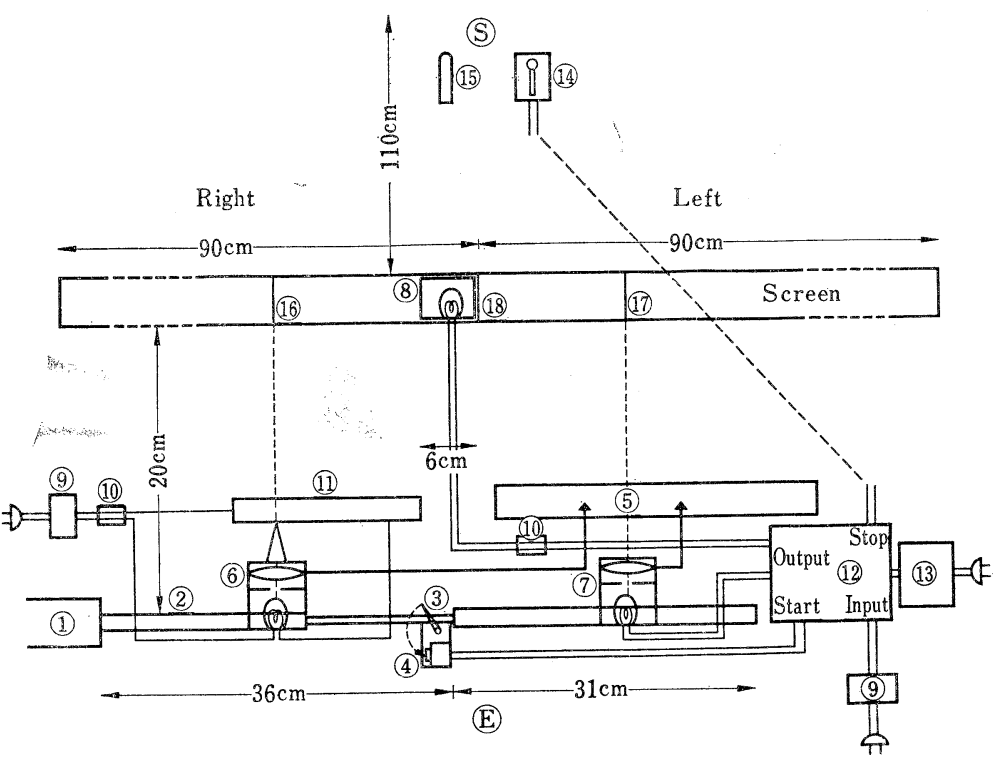

FIG. 2. The apparatus for presenting stimuli.

(1) Cylinder. (2) Piston. (3) Timer. (4) Microswitch. (5) Memory drum. (6) Lamp-house for standard stimulus, in which there are a lamp of $6 \mathrm{~V}$, a slit and a 4 lens. (7) Lamphouse for reproduction stimulus, which is as same as that for standard stimulus. (8) Lamphouse for space reproduction, in which there are a lamp of $6 \mathrm{~V}$ and a slit. (9) Transformer. (10) Switch. (11) Rail for standard space. (12) Reaction controller. (13) Electric timer. (14) Key, by which subjects can switch off the lamp in the lamp-house for reproduction stimulus. (15) Bar, by which subjects can move freely the lamp-house for reproduction stimulus. (16) Image of light: Standard stimulus $(3 \mathrm{~cm} \times 1 \mathrm{~mm})$. (17) Image of light : Reproduction stimulus $(3 \mathrm{~cm}$ $\times 1 \mathrm{~mm})$. (18) Image of light: Stimulus for space reproduction $(3 \mathrm{~cm} \times 1 \mathrm{~mm})$.

2 この装置全体は広島大学河原淳夫助教授のデザイン 3 この部分は科研共栄会に拈いて作られた。 による。記して感謝の意を表す。 
TABLE 3

Values of time, space and velocity of standard stimuli, when reproductions are done for time, space and velocity respectively

\begin{tabular}{c|c|c|c}
\hline $\begin{array}{c}\text { Object reproduced } \rightarrow \\
\downarrow \text { Number of condition }\end{array}$ & Time & Space & Velocity \\
\hline T sec & 2 & 0.8 & 1 \\
(1) $\quad$ E cm & 4 & 8 & 4 \\
V cm/sec & 2 & 10 & 4 \\
T sec & 8 & 8 & 8 \\
(2) $\mathrm{E} \mathrm{cm}$ & 4 & 4 & 4 \\
V cm/sec & 2 & 4 & 5 \\
(3) $\mathrm{T} \mathrm{sec}$ & 20 & 8 & 20 \\
E cm & 10 & 2 & 4
\end{tabular}

こでもその運動を止めることができる，速度調節器のバ ルブの回転によって油流量を変光ることにより，速度は いつでも連続的にか觉るとがでさる、その範围は，0.8 $\mathrm{cm} / \mathrm{sec}$ から $20 \mathrm{~cm} / \mathrm{sec} て ゙$ 岁.

次に刺激提示のための装置についてのべる(Fig. 2). まず標準刺激の提示装置について．前述のシリンダーの ピストン上に標準刺激用ランプハウスが固定されて括 り，そのランプハウスはピストンとともに $30 \mathrm{~cm}$ の距離 を左右に運動する。 ランプハウスの中には $6 \mathrm{~V}$ の豆電球， スリット执よび凸レンズがそな兄らて和り，そのラン プハウスの前方 $20 \mathrm{~cm}$ のスクリーン上に長さ $3 \mathrm{~cm}$ 幅 1 $\mathrm{mm}$ の線条の像を結ぶようになっている，そのランプ、 ウスの先端は電導体に接触し，電導体に接触している間 だけランプがつくようにすることにより，電導体の位置 と長さで標準刺激の位置と長さは自由に変えられる。 こ の実験では刺激の消光る地点はつね正中面より被験者 に向って, 右 $6 \mathrm{~cm}$ のころに定めてあるので, 標準刺 激は $0 \mathrm{~cm}$ から $24 \mathrm{~cm}$ まで自由に変えられる。 またこの ピストンの速度は手元の速度調整器で自由に変えること ができる。したがって，標準刺激の距離と速度を自由に 変えることができ，時間もその組合せによって自由に変 えることがでさる。この標準刺激用ランプハウスの運動 はすべて，1 $1 \mathrm{~cm} / \mathrm{sec} の$ 速さで回転する記録ドラムに記録 される，このランプハウスを出発点にもどす時は， ラン プがつかないようランプのスイッチを切る.

次に再生刺激について述べる，標準刺激用ランプハウ スは正中面より右 $6 \mathrm{~cm}$ の所にきた時，マイクロスイッ チ付属のタイマーの先端を押し，そのタイマーの先端は 1 秒後にマイクロスイッチのスイッチを押す．それによ って再生刺激用ランプハウスと空間再生用ランプハウス のランプがつく。再生刺激用ランプハウス内の構造は標 準刺激用ランプハウスのそれとまったく同様で, 正中面
TABLE 4

Subjects

\begin{tabular}{c|l|c|c}
\hline \multicolumn{1}{c|}{ Group } & Sex & Number & $\begin{array}{c}\text { Mean } \\
\text { age } \\
\text { years : } \\
\text { months }\end{array}$ \\
\hline $\begin{array}{l}\text { E 2 Elementary school } \\
\text { children (2 nd grade) }\end{array}$ & Male & 9 & $7: 8$ \\
Female & 9 & $7: 10$ \\
children (4 th grade) & Female & 9 & $9: 9$ \\
$\begin{array}{l}\text { U Undergraduate } \\
\text { university student }\end{array}$ & Male & 9 & $18: 10$ \\
& Female & 9 & $18: 6$
\end{tabular}

より左 $25 \mathrm{~cm}$ を自由に被験者または実験者が動かすこと ができる，空間再生用ランプハウスは，スクリーンのす ぐうしろに固定されて扔り，この中に恬 $6 \mathrm{~V}$ の豆電球が 入って括り, 正中面長さ $3 \mathrm{~cm}$ 幅 $1 \mathrm{~mm}$ のスリットが 岁るから，スクリーン上にぼ標集制激や再生刺激とほぼ 同じ刺激がみられる.さらにマイクロスイッチはT.K.K. Reaction controller 特よび Electric timer 亿接続して 和り，再生刺激用ランプのついている間 Electric timer が働く。

時間の再生の際には，空間再生用ランプハウスのスイ ッチは切ってあり，再生刺激用ランプハウスは正中面比 固定されている。空間の再生の際には，空間再生用ラン プハウスのスイッチは入れて文り，再生刺激用ランプハ ウスは各試行のはじめにあるさだめられた位置に乱かれ ている。速度の再生の際には，空間再生用ランプハウス のスイッチは切ってまり，再生刺激用ランプハウスは各 試行の初めには, 正中面位置している。

最後に被験者のがわから見た装置さのべる、被験者の 前方 $110 \mathrm{~cm}$ の所に, 縦 $66 \mathrm{~cm}$, 横 $180 \mathrm{~cm}$ の死色のつ いたてがあり，そこに幅 $3 \mathrm{~cm}$ ，長さ $180 \mathrm{~cm}$ のトレッシ ングペーパーをはった承平のス少リーンがある。このス クリーンは刺激の運動距離に比較しは添無限距離と思わ れる、すなわら空間的枠組を水平方向に関して最少にし てある。被験者の手元には再生刺激用ランプハウス觉動 かすためのバーと，再生刺激用ランプを消すためのキー とがある。バーの動きは平行移動装置により再生刺激用 ランプハウスの動きと 1 対 1 に対応する。キーは Reaction controller 通じ Electric timer 接続している.

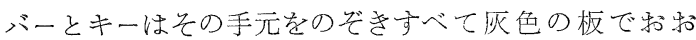
い，部屋はうすぐらくして岗り，なたスクリーン以外は すべて灰色なので, 被験者は光刺激以外は明瞭に見るこ とはでさない。

以上の装置は次の 2 点で不完全であった，その $1 つ$ は, 速度調整器による種々の值の速度の再現の際の正確 度がやや劣ることである。しかし值の時間的変化はかな 
TABLE 5

Analysis of variance baced on Fig. 3

\begin{tabular}{lr|r|r|r}
\hline \multicolumn{1}{c|}{ Source } & & $d f$ & $m s$ & $F$ \\
\hline Between-Subjects & & 53 & & \\
Sex & B & 1 & 1,915 & - \\
Age & C & 2 & 13,592 & $4.51^{* * *}$ \\
Error (b) & B C & 2 & 1,635 & - \\
\hline Within-Subjects & & 48 & 3,015 & \\
Condition & A & 2 & 1,669 & 1.94 \\
& A B & 2 & 2,538 & $2.95^{*}$ \\
& A C & 4 & 409 & - \\
Error (w) & & 4 & 316 & - \\
Total & & 161 & 862 & \\
\hline To & & &
\end{tabular}

$* * p<.05, * p<.10$

り一定したものであったので，岕らかじめそれを充分に しらべ，その変化を修正しながら実験を行ない，さらに 標準刺激の運動をすべて記録ドラムに記録することによ ってチェックし，測度として再生值とのものをあつかわ ず,標準值に対する再生值の百分比学用いることにより，

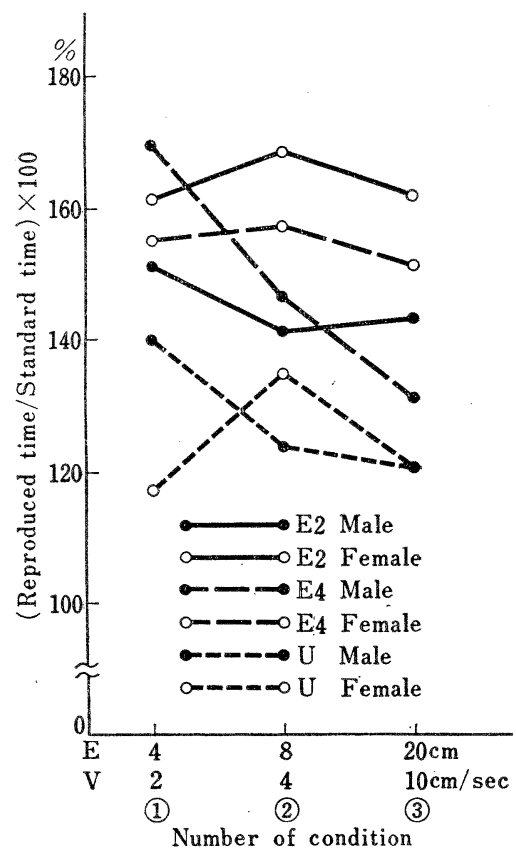

FIG. 3. Reproduction of the constant physical time, that is, $2 \mathrm{sec}$, for each condition of standard stimulus.
TABLE 6

Analysis of variance baced on Fig. 4

\begin{tabular}{lr|r|r|r}
\hline \multicolumn{1}{c|}{ Source } & & $d f$ & $m s$ & $F$ \\
\hline Between-Subjects & & 53 & & \\
Sex & B & 1 & 791 & - \\
Age & C & 2 & 6,777 & 1.72 \\
& B C & 2 & 2,947 & - \\
Error (b) & & 48 & 3,946 & \\
\hline Within-Subjects & & 108 & & \\
Condition & A & 2 & 205 & - \\
& A B & 2 & 187 & - \\
& A C & 4 & 809 & $3.33^{* *}$ \\
Error (w) & & 96 & 243 & $2.83 * *$ \\
Total & & 161 & & \\
** $p<$.05 & & & &
\end{tabular}

この久点を和ぎなった。もう 1 つ速度を再生するため の平行移動装置が完全でなく, 岁る程度速い速度の再生 はスムーズにできるが，遅い速度の再生には技巧を要し た。したがって，再生の容易な範囲内の速度を実験に用 いるようにした。

時間，空間特よび速度評洒の方法. 長さ $3 \mathrm{~cm}$, 幅 1 $\mathrm{mm}$ の標準刺激が下記に述べるような時間，空間和よび

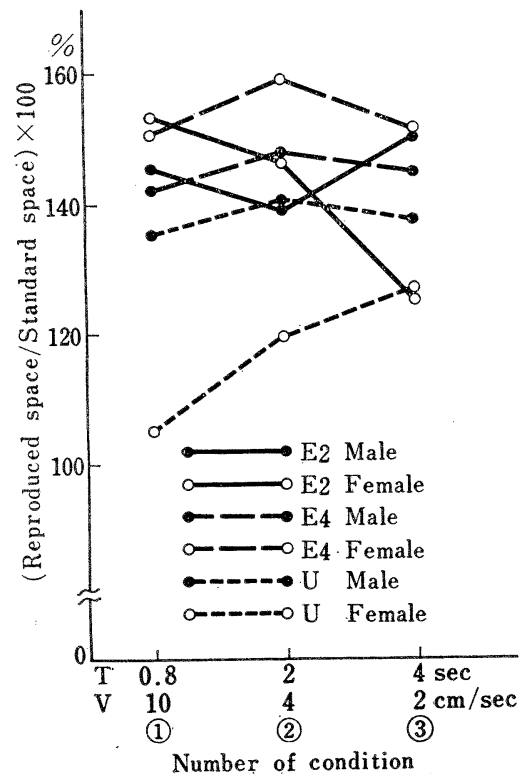

FIG. 4. Reproduction of the constant physical space, that is, $8 \mathrm{~cm}$, for each condition of standard stimulus. 
TABLE 7

Analysis of variance baced on Fig. 5

\begin{tabular}{|c|c|c|c|c|}
\hline \multicolumn{2}{|c|}{ Source } & $d f$ & $m s$ & $F$ \\
\hline \multicolumn{2}{|c|}{ Between-Subjects } & 53 & & \\
\hline Sex & B & 1 & 216 & - \\
\hline \multirow{2}{*}{ Age } & $\mathrm{C}$ & 2 & 36,078 & $10.30 * *$ \\
\hline & $\mathrm{BC}$ & 2 & 8,911 & $2.54^{*}$ \\
\hline \multicolumn{2}{|c|}{ Error (b) } & 48 & 3,503 & \\
\hline \multicolumn{2}{|c|}{ Within-Subjects } & 108 & & \\
\hline \multirow[t]{4}{*}{ Condition } & A & 2 & 27,818 & $35.20^{* *}$ \\
\hline & A B & 2 & 694 & - \\
\hline & $\mathrm{AC}$ & 4 & 892 & 1.13 \\
\hline & $\mathrm{ABC}$ & 4 & 1,664 & 2. $11^{*}$ \\
\hline \multicolumn{2}{|c|}{ Error (w) } & 96 & 790 & \\
\hline \multicolumn{2}{|c|}{ Total } & 161 & & \\
\hline
\end{tabular}

速度条件の 1 つに従って, 被験者の正面のスクリーンの 右手を右から左へ運動する，その運動が終る地点はどの 条件に和いてるつ称に一定である. 連動が終って 1 秒後 に，その地点から $6 \mathrm{~cm}$ 左に再生用の，標準刺激と同じ 形の光線が岕らわれる。時間評洒の際は, 被験者は, そ の再生用の刺激が標準刺激がついていたと同じ時間つい ていたと思った時，手元のキーを押して光の線を消す. 光の線のついていた時間は Electric timer に記録され る。時間評価の際，数をかでえたり拍子をとることは禁 ずる，空間評価の際は，再生用の光線がもう $1 つ 4 \mathrm{~cm}$ または $16 \mathrm{~cm}$ はなれて同時につく. 被験者は手元のバー を動かすことにより，その光線を動かし，2 つの光線の 間隔が標準刺激の運動距離と等しくなるようにする。実 験者は，その時の 2 つの光線の距離を 2 つランプハウ スの距離から読みとった後, 光線を消す。速度評洒の際 は，被験者は手元のバー学動かすことにより，再生用光 線を標準刺激の運動速度と主観的に同じ速さで動かす。 その際, 標準刺激の運動距離に関係なくバーはつきあた るまで動かさなければならない。この実際の運動距離は $25 \mathrm{~cm}$ であるが，被験者にはどこまで動かせばよいか岁 らかじめわからない，再生刺激の運動はすべて先述の記 録ドラムに記録される.最初の $5 \mathrm{~cm}$ の運動は不規則な のでのぞき，市と $20 \mathrm{~cm}$ の平均速度を測度とする。この ような評価方法を用いることにより，時間，空間，速度 起それぞれ他のものとは切りはなして再生させうるよう にした。

刺激条件 標準刺激の刺激条件は Table 3 のと特りで 安る。

手続 実験は 1 人ずつ行なわれる，各人空間，時間，
速度評価のすべてを行ならが，その3つの評価のどれか らはじめるかは，ランダムにする，各評洒内の3つの笨 件はランダムに2回ずつ行なう。本試行に入る前に装置 と評価方法に充分なれさせるため，すくなくとも2回の

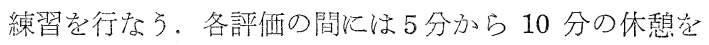
入れる。実験は全部で 1 人 40 分から 1 時間である。実 験には年少児も興味を持って参加した。

被験者 被験者はTable 4 のようで岕る。

\section{結 果}

時間評価 まず時間評㑡について述べる，我々は再生 時間そのものをあつかわないで，標準時間に対する再生 時間のパーセンテージを測度とする。各条件に 2 回反底 しているが，そのパーセンテージの平均值をとり岕つか 5. 各グループの各条件に対する平均值索女別に示す と Fig. 3 のよらである。分散分析の結果を $5 \%$ 水準て

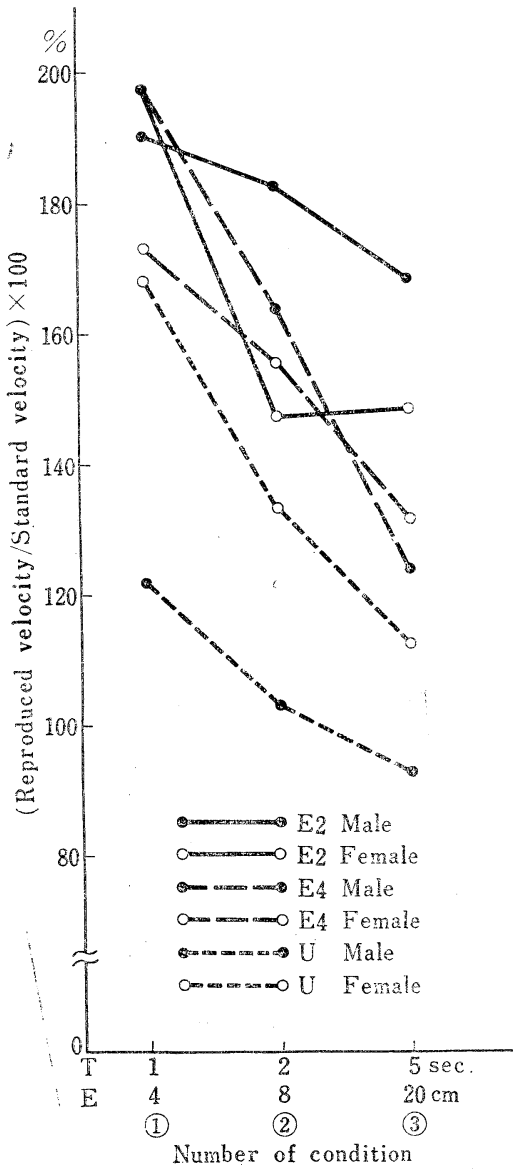

FIG. 5. Reproduction of the constant physical velocity, that is, $4 \mathrm{~cm} / \mathrm{sec}$, for each condition of standard stimulus. 
TABLE 8

Numbers of subjects whose relations of reproduced values are (1) $\left\langle^{\dagger}(3),(1) \div(3) \text {, and (1) }\right\rangle^{\dagger}$ (3) respectively

\begin{tabular}{|c|c|c|c|c|c|c|c|c|c|}
\hline Object reproduced & \multicolumn{3}{|c|}{ Time } & \multicolumn{3}{|c|}{ Space } & \multicolumn{3}{|c|}{ Velocity } \\
\hline $\begin{array}{l}\text { Relation } \\
\text { (Result) }\end{array}$ & (1) $\underset{(i)}{<}$ & $\div$ & 1) $\underset{\left(i^{\prime}\right)}{>(3)}$ & (1) $<$ (ii) & $\div$ & (1) $\underset{\left(\mathrm{ii}^{\prime}\right)}{(3)}$ & (1) $<$ (iii) & $\div$ (3) & (1) $\underset{\left(\mathrm{iii}^{\prime}\right)}{>(3)}$ \\
\hline E 2 & 5 & 7 & 6 & 4 & 6 & 8 & 4 & 1 & 13 \\
\hline E 4 & 4 & 5 & 9 & 6 & 8 & 4 & 0 & 3 & 16 \\
\hline $\mathrm{U}$ & 5 & 6 & 7 & 10 & 6 & 2 & 0 & 2 & 17 \\
\hline
\end{tabular}

$\dagger<$ or $>$ means that (reproduced value/standard value) 100 for (1) is smaller or larger than that for (3) by above $10 \%$.

TABLE 9

Relations between time estimation and space estimation (unit : number of subjects)

E 2

\begin{tabular}{|c|c|c|c|}
\hline $\begin{array}{l}\text { Space } \rightarrow \\
\text { Time } \downarrow\end{array}$ & (1) $<$ (3) & $(1) \div(3)$ & (1) $>$ (3) \\
\hline (1) $<$ (3) & 1 & 1 & 3 \\
\hline (1) $\div$ (3) & 2 & 4 & 1 \\
\hline (1) $>$ (3) & 1 & 1 & 4 \\
\hline
\end{tabular}
E 4

\begin{tabular}{|c|c|c|c|}
\hline $\begin{array}{l}\text { Space } \rightarrow \\
\text { Time } \downarrow\end{array}$ & (1) $<$ (3) & (1) $\doteqdot(3)$ & (1) $>$ (3) \\
\hline (1) $<$ (3) & 1 & 2 & 1 \\
\hline (1) $\div$ (3) & 1 & 2 & 2 \\
\hline (1) $>$ (3) & 4 & 4 & 1 \\
\hline
\end{tabular}

$\mathrm{U}$

\begin{tabular}{|c|c|c|c|}
\hline $\begin{array}{l}\text { Space } \rightarrow \\
\text { Time } \downarrow\end{array}$ & (1) $<$ (3) & $(1) \div(3)$ & (1) $>$ (3) \\
\hline (1) $<$ (3) & 4 & 1 & 0 \\
\hline (1) $\div$ (3) & 5 & 0 & 1 \\
\hline (1) $>$ (3. & 1 & 5 & 1 \\
\hline
\end{tabular}

TABLE 10

Relations between time estimation and space estimation, when subjects belonging to (1) $\doteqdot$ (3) are divided into (1) $<$ (3) and (1) $>$ (3) in half (unit : number of subjects)

E 2

\begin{tabular}{l|cc}
\hline $\begin{array}{c}\text { Space } \rightarrow \\
\text { Time } \downarrow\end{array}$ & (1) $<$ (3) & (1) $>$ (3) \\
\hline (1) $<$ (3) & 3.5 & 5.0 \\
(1) $>$ (3) & 3.5 & 6.0
\end{tabular}

検定したところ, Table 5 のよ5に年令の効果のみ有意 である。すなわち大学生群の平均值 125.9 は, 小学 2 年 生: 小学 4 年生の $154.7,151.9$ より有意に小さい。 ころで条件と性の交互作用が $10 \%$ 水準で有意であるの で，その点から Fig。 3 をみると，各年令段階に一貫し て，男女別々の傾向がみられる。すなわち男子では空間 が長くなり速度が速くなるほど，時間の評価が短くなる 傾向（i'の傾向）がみられるが，女子ではみられない.

空間評価 空間評価についても同様にパーセンテージ を測度とする，各グループの各条件に対する平均值を男 女別に示すと Fig. 4 のようである. 分散分析の結果を $5 \%$ 兆準で検定したところ Table 6 のよ5に条件と年令 の交互作用。条件と年令と性の交互作用が有意であっ た。すなわら, 小学 2 年生では時間が短くなり速度が速 くなると架間は長く評価され ( $\mathrm{ii}^{\prime}$ の結果), 小学 4 年生 では条件差なく，大学生では逆に空間は短く評価される (ii の結果). 乙かもそのよ5な条件と年令の交互作用は 女子にのみはっきりみられ，男子ではどの年令段階に拉 いても有意な条件差はみられない。 $\mathrm{U}$

\begin{tabular}{c|cc}
\hline $\begin{array}{c}\text { Space } \rightarrow \\
\text { Time } \downarrow\end{array}$ & (1) $<$ (3) & (1) $>$ (3) \\
\hline (1) $<$ (3) & 7.0 & 1.0 \\
(1) $>$ (3) & 6.0 & 4.0
\end{tabular}

速度評価 速度評洒に特いても同様にパーセンテージ を測度とする，各グループの各条件に対する平均值を男 女別に示すと Fig. 5 のよらである. 分散分析の結果は Table 7 のよ5に, 年令の効果と条件の效果が有意であ る.すなわら平均パーセンテージは大学生, 小学 4 年 生, 小学 2 年生となるにつれ，150.4, 157.4, 172.0 と 増加する。しかし空間が長くなり時間が長くなると速度 が遅くみ元る( iii $^{\prime}$ の結果) というのは各年令, 性を通じ て共通である。また性と年令の交互作用が 10\% 水準で 有意であるが，これは年令の効果が男子で大きく，女子 で小さい傾向を示している，さらに性と年令と条件の交 互作用も $10 \%$ 水準で有意であるが，これは主に小学 4 年生の男子に称いて条件效果が大きいことによる。

これまでパーセンテージの平均值を岁つかってきた が，次に反応のパターンを分類し，それにらくまれる人

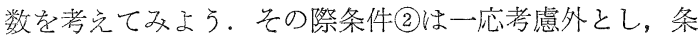
件(1)に対するパーセンテージと条件(3)に対するとれとの 差が 10\%以上の時，ある傾向めりとする。そこで時間， 空間, 速度評価の各々について，ぞのょうな傾向を何人 
が示すかを表にすると Table 8 のよである。この表の 結果は当然のことだが Fig. 3,4,5 と対応したものであ る.ささてそこで, 時間, 空間, 速度の各評価間の関係を みよう。ところで速度の評価は Table 7 亿みるように小 学 2 年生から大学生まで㴗とんぞ (1)> (3) (iii') である から,一応これはのぞき, 時間評価と空間評価の関係を見 る. その結果は Table 9 のとうりで, 両者の関係が年令 ととも変わっている傾向がうかが兄る。ささらに(1) のものを(1)<(3) と (1)>(3) 江半数づつにわけると Table 10 のようになる。この 2 つの表から, 小学 2 年生に特 いては, 時間評価比いて(1)>(3)(i') でかつ空間評価に おいて (1)>(3)(ii')のものがかなり多く, 小学 4 年生で は (1)>(3)(i')から (1)<(3)(ii) の関係のものが多い傾向が 出り, 大学生では (1)<(3) ( i ) かつ (1)<(3)(ii) のものが 出らわ机る傾向の岕ることがよ又とれる。

\section{考察}

まず時間評価についてみると，客観的には同じ時間の 長さも空間や速度によって主観的長さがことなるという ことは，ぞの年令群に特いてもあまり明膫ではないが， 傾向としては，特に男子に扬いて，kappa-effect と逆の 効果がみられる。したがって，これまでの動体を用いた 実駼結果 (Bonnet, 1965 ; Brown, 1931 b) と矛盾しな

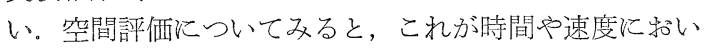
てことなるということは，女子に执いてはっきりとみら 机る。しかも年少児では tau-effect と逆の方向に, 年長 者では tau-effect の方向である. Mashhour(1964)の成 人を用いた広範な実験では。成人に物いて子我々の年少 児と同様むしろ tau-effect と逆の効果を示して招り, 我 々の結果と一致しない. 残念なことに, 彼は時間評価に 特いて kappa-effect と同方向の効果が岕るかどうかを 調べていない,ところで, 我々の結果に数いて注目すべ きことは, tau-, kappa-effect という時空相待現象と同 方向の效果を示す者は大学生にはかなりみられるが, 小 学 1 年生では, そのまったく逆の傾向を示するのが優勢 でめり, 小学 4 年生がその中間段階にあるということで 岕る。時空相待現象が確立した事実であることは認める が，乙かしこの現象も発達的牦再検討してみる必要が女 りそらである。な特, 動体を用いた実験と, 点滅する静 止刺激を用いての時空相待現象を調べた実験之は，その 時間, 空間の值飞执いても, 前者の方が值が大きい傾向 が岕る、また Scholz (1924) の広範な研究結果が示すよ うに, tau-effect も時間空間の值によってその方向が逆

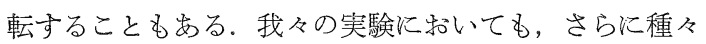
の標準刺激の值を使って実験せね礼ばならない。

速度評価注いてみると, その時間, 空間に上る効果 は各年令を通じて同じ方向にきわめてはっきりとみられ る.すなわち空間が長くなり時間が長くなると, 同じ速
度でも遅く評価されるということである。これはMashhour が $l$-effect と名づけたものと対応し, Bonnet (1964), Brown (1931 a) の結果とも一致する。末た Cohen (1967) は現象的な距離と現象的速度との関係 ミューラーリャ一の錯視を用いて調べ, 物理的距離が等 しくても現象的距離がことなれば $l$-effect と同様の効果 を岁らわすことを示した。このように，動体の速度評価 の際， $l$-effect はかなりはっきりとした事実と思われる. そして Johanson (1962) が MTE と名づけた，動体によ って運動された距離は静止的距離より長く知覚される, という現象と連続するものかもしれない。

さて, 実験結果を発達的にみたとき, 最初の予想, 寸 なわち評価の際の時間, 空間, 速度の依存関係から独立 関係への発達傾向の予想は岕たらなかった。事態はもっ と複雑で步り，空間評価のよう飞依存的関係が年令に上 って反転する傾问のものもあり，また速度評価のように 年少児から成人まで一貫して，亦るいはむしろ年長者に なるほど強い依存関係を示するのも牢った。我及はさら に種々の標準刺激を用意する実験を行ない,この点を 明らかにしていかね水ならない。もう1つ発達傾向とし て認められるのは, いずれの評洒淿特いても再生值が標 準值よりも大きく，しかもそれが年少罗添ど著しいこと で岁る。ただし空間評価化执いては有意差はない，年少 児の方が再生が不正確なわけで岕るが単なる不正確さ で岁れば，標準值よりも大きいのも小さいのも岕るはず で岁る。このような発達段階が低い浮ど, 再生值が標準 值より一定方向にずれるということは, 時間評価の研究 （松田，1965 a, b，1966）飞特いてもみられたことであ る.

\section{要 約}

この実験の目的は, 動体の時間, 空間, 速度評価の 3 者間依存関係があるかどらか，あるとすればそれはす で確立された事実である時空相待現象をふくもるのか ぞうか，そして発達的に先の関係はどのように変わるか を検討することである。

方法は再生法を用い，動体の時間，空間，速度をとれ ぞれ切りはなして再生させた。被験者は小学 2 年生, 小 学 4 年生, 大学生である. 結果は次のようであった。

1. 同じ運動時間でも，空間（運動）距離が長くなり 速度が速くなると，短かく評価される傾向が，特に男子 にみられた。

2. 小学 2 年生では, 同じ空間でも, 時間が短くなり 速度が速くなると, 長く評価され, 小学 4 年生では效果 なく, 大学生では逆の効果があった。この傾向はどの年 令でも女子に著しかった。

3. 同じ速度でも，空間が長くなり時間が長くなると 遅く評価されるということが，すべての年令群を通じて 
強く見られた。

4. 時間和よび速度評洒に和いて，年少览注ぞ，再生 值が標準值より大きかった。

5. 時間が長いと空間が長く評価され，空間が長いと 時間が長く評価されるとい5，いわゆる時空相待現象と 同方向の効果を，この動体に括ける事態でも示した者は 大学生に多く, 小学 2 年生では逆の方向の者が多く, 小 学 4 年生はその中間段階であった。

\section{引用 文 献}

阿部孫四郎 1936 時間知覚上の空間効果 実験心理学 研究, 3, 1-52.

阿部孫四郎 $1937 \mathrm{a}$ 時間直観上の空間の作用 実験心 理学研究, 4, 1-12.

阿部孫四郎 $1937 \mathrm{~b}$ 空間直観上の時間の作用 実験心 理学研究, 4, 83-93.

阿部孫四郎 $1937 \mathrm{c}$ 時空相待一文献的並飞実験的研究 実験心理学研究，4，161-194.

Abe, S. 1935 Experimental study on the co-relation between time and space. Tohoku Psychol. Folia, 3, 53-68.

Bonnet, C. $1964 \mathrm{La}$ vitesse perçue et la relation v $=\mathrm{e} /$ t. Ann. Psychol., 64, 47-60.

Bonnet, C. 1965 Influence de la vitesse du mouvement et de l'espace parcouru sur l'estimation du temps. Ann. Psychol., 65, 357363.

Brown, J.F. 1931 a The visual perception of velocity. Psychol. Forsch., 14, 199-232.

Brown, J.F. $1931 \mathrm{~b}$ On time perception in visual movement fields. Psychol. Forsch., 14, $233-248$.

Cohen, R. C. 1967 On the relationship between phenomenal velocity. Scand. J.Psychol., 8, $107-118$.
Cohen, J., \& Cooper, P. 1963 Durée, longueur et viyesse apparentes d'un voyage. Ann. Psychol., 63, 13-27.

Cohen, J., Cooper, P., \& Ono, A. 1963 The hare and the tortoise : A study of the tau-effect in walking and running. Acta Psychol., 21, 387-393.

Cohen, J., Hansel, C. F. M., \& Sylvester, J. D. 1955 Interdependence in judgements of space, time and movement. Acta Psychol., 11, $360-380$.

Ekman, G., \& Dahlbäck, B. 1956 A subjective scale of velocity. Rep. Psychol. Lab., Univer. Stockholm., No. 31.

Helson, H., \& King, S. M. 1931 The tau-effect. An example of psychological relativity. J.exp. Psychol., 14, 202-217.

Johanson, G. 1962 Perceptual overestimation of small motion tracks. Psychol. Beiträge, 6, $570-580$.

Mashhour, M. 1964 Psychophysical relations in the perception of velocity. Almqvist \& Wiksell: Stockholm.

松田文子 1965a 時間評価の発達 I 一聴覚的言語刺激 のまとまりの効果一 心研, 36, 169-177.

松田文子 $1965 \mathrm{~b}$ 時間評価の発達而一標準時間中の音 の頻度の効果一 心研, 36, 285-294.

松田交子 1966 時間評価の発達而一標準時間中和よび 再生時間中の音の頻度の効果一 心研, 37,352 $-357$.

Scholz, W. 1924 Experimentalle Untersuchungen über die phänomenale Grösse von Raumstrecken, die durch Zukzessiv-Darbietung zweier Reize begrenzt werden. Psychol. Forsch., 5, 219-272.

\title{
DEVELOPMENTAL STUDY OF TIME, SPACE AND VELOCITY ESTIMATIONS : I
}

\author{
FUMIKO MATSUDA
}

Hiroshima University

\section{ABSTRACT}

The present experiment is a develop- mental study on interactions of estimated time, space and velocity. Psychological relativity in perception of time and space is 
well-known as tau-effect and kappa-effect. Although the effects are dynamic, static stimuli are usually used in these investigations. In the field of motion perception there are several investigations concerning interaction of time, space and velocity and most of the research failed in verifying the existence of tau- and kappa-effect.

There are two methods in dealing with known and unknown qualities (Table 1). We adopted the Method I as it is simpler. Possible results in the case of Method I are shown in Table 2.

Developmental investigation may make the interacting effects more clear, as young children may estimate time, space and velocity more interdependently than adults. The types and the number of subjects are in Table 4.

The standard stimulus, a light patch, moves from right to left on the right side of the screen, in accordance with the conditions shown in Table 3 . The reproduction stimulus, another light patch, appears on the left side of the screen when the exposure time of the standard stimulus is estimated. Subjects are requested to push the key when perceived exposure time of the reproduction stimulus equals to that of the standard. Two light patches used for reproduction of the spatial distance are presented one second after the standard stimulus disappeared. Subjects are requested to adjust the reproduction stimulus to the spatial distance of the stimulus.

The subjective velocity is measured by adjusting the reproduction stimulus to the phenomenal velocity of the standard (see Fig. 1 and 2).

Results are as follows :

1. There is a tendency especially for male subjects to underestimate the constant physical time ( $2 \mathrm{sec}$ ), as velocity and spatial distance become larger (see Fig. 3 and Table 5).

2. Female subjects in E2 group overestimate the constant spatial distance $(8 \mathrm{~cm})$, as exposure time becomes shorter and velocity becomes larger, but female subjects in $U$ group show different tendency (see Fig. 4 and Table 6).

3. All groups underestimate the constant physical velocity $(4 \mathrm{~cm} / \mathrm{sec})$ as time and spatial distance become larger (see Fig. 5 and Table 7).

4. Most of the subjects who show such relations as tau-and kappa-effect between time and space estimation belong to $U$ group. But inverse relation is rather strong in $\mathrm{E} 2$ group. 